\title{
The Cyclicality of Loan Loss Provision and Income Smoothing Behavior of Commercial Banks Pre and Post IFRS: Evidence from Ethiopia
}

\author{
Simeneh Almaw Molla \\ Department of Accounting and Finance, Debre Markos University, Ethiopia
}

\begin{abstract}
Loan loss provision is the significant accrual in the banking sector. This accrual is necessary to lessen the expected credit losses, but in some extent, these accruals would be used for earning management purpose. Thus, the main purpose of this paper is to examine the cyclicality of loan loss provisions and income smoothing behavior of Ethiopian commercial banks in comparison of pre and post IFRS. Explanatory type of research design applied in this research. The paper used unbalanced panel of Ethiopian commercial banks for the period 2010-2019. In order to examine the income smoothing behavior and the cyclicality loan loss provisioning system, pooled panel data regression model has been used following the appropriate test and the complete specification of the model. The result of this paper revealed that loan loss provision of commercial banks in Ethiopia follows a dynamic provisioning system. There is also an evidence that support the existence of income smoothing behavior after IFRS adoption but not before. Moreover, this paper supports the capital management hypothesis and the result shows that IFRS do not intervene for capital management behavior of Commercial banks. Thus, the paper concludes that IFRS adoption in Ethiopian commercial banks do not enhance the reporting quality of banks. These findings suggest that the regulatory body of commercial banks (National bank of Ethiopia) and the regulatory body (including councils) of financial reporting (Accounting and audit board of Ethiopia) should strictly follow-up the adoption of IFRS in the banking sector.
\end{abstract}

DOI: $10.7176 /$ RJFA/12-3-02

Publication date: February $28^{\text {th }} 2021$

\begin{abstract}
ABOUT THE AUTHORS
This is to inform you that the manuscript entitled as "The cyclicality of loan loss provision and income smoothing behavior of commercial banks pre and post IFRS: evidence from Ethiopia" is our own research work. Simeneh Almaw Molla and Dr. Beza Muche Teka are currently working as a lecturer and assistant professor as well as researcher (respectively) in Debre Markos University, Ethiopia, College of Business and Economics, Department of Accounting and Finance. Simeneh Almaw have 5 years teaching and research experience and Dr. Beza Muche have more than 13 teaching and research experience. Dr. Beza Muche has six publications in reputable international journals and Simeneh Almaw has one publication in international journal. Loan loss provision is a significant accrual account of banks which determines their risk exposure. Moreover, based on the international experience, banks earning management is the hot issue. According to the empirical evidence, Banks smooth their earning through loan loss provision. However, it is the ignored issue in the Ethiopian literature. Therefore, the examination of the loan loss provision and the income smoothing behavior of commercial banks will have tremendous benefit for the bank regulators, auditors and investors. It will also highlight on the role of IFRS for reporting quality. Further, it helps to fill significant literature gap and thereby it will give insights for future researchers about the earning management problems and will stimulate further investigation of the issue.
\end{abstract}

\section{PUBLIC INTEREST STATEMENT}

Loan loss provision is a significant accrual account of banks which determines their risk exposure. Moreover, based on the international experience, banks earning management is the hot issue. According to the empirical evidence, Banks smooth their earning through loan loss provision. However, it is the ignored issue in the Ethiopian literature. Therefore, the examination of the loan loss provision and the income smoothing behavior of commercial banks will have tremendous benefit for the bank regulators, auditors and investors. It will also highlight on the role of IFRS for banks reporting quality enhancement. Further, it helps to fill significant literature gap and thereby it will give insights for future researchers about the earning management problems and will stimulate further investigation of the issue.

Keywords: loan loss provision; Cyclicality; income smoothing; Commercial banks; IFRS; and Ethiopia.

\section{Introduction}

Bank loan loss provision is an amount set aside by banks to mitigate expected losses on the bank loan portfolio (Yang, 2001 as cited in Desta, 2017; Alhadab \& Alsahawneh, 2016). Banks accept deposits and provide loans for borrowers with reasonable interest rates. The interest rate charged by banks is based on the market rate, and 
company-specific credit risk. If lending rates accurately reflected credit risks and as capital is still needed to cover unexpected losses, why banks set aside additional provisions? Provisions would be appropriate if the riskiness of the loan cannot be predicted. Loan loss provision recognize the higher discount rate and reduced likelihood of repayment or equivalently the value of the loan would be marked down as part of a fair value accounting approach. similarly, banks might even take negative provisions if riskiness were reversed. In other token, banks have discretionary power to vary loan loss provisions from negative to positive (max limited on the amount of total loan) for/by different motives (Desta, 2017; Alhadab \& Alsahawneh, 2016, Laeven \& Majnoni, 2003).

The issue of loan loss provisions and earning management, in the banking industry, attract the attention of wide literatures. According to Dermine and Carvalho (2008) appropriate amount of loan loss provision is needed for banks profitability, capital adequacy and solvency measurement. But, As documented in Othman \& Mersni (2014), around the world, banks are found to manage their earnings to minimize the earnings volatility over time through loan loss provision. Many of the current literatures also evidenced that banks use loan loss provision as an instrument for income smoothing (Fonseca \& Gonzalez, 2008; Boudriga, Zouari \& Taktak, 2010; Leventis, Dimitropoulos \& Anandarajan, 2011; El Sood, 2012; Othman \& Mersni, 2014; Pool, Haan, \& Jacobs, 2015; Alhadab \& Alsahawneh, 2016; Desta, 2017; Ozili, 2017; Ozili \& Outa, 2018). However, most of the existing literatures focused on the provisioning system and income smoothing practice of banks in developed countries. But less emphasis is given in the case of developing countries. Recently, Desta (2017) and Ozili (2018 and 2019), was tried to investigate the loan loss provision practice of African banks. However, these researchers excluded Ethiopia from the scenario. But, the problem of loan loss provision is different in Ethiopia as compared to other African countries bank because of the market nature (no stock market).

Furthermore, the existing loan loss provision literature is full of mixed results. For instance, Boudriga et al. (2010) and Othman and Mersni (2014) found an evidence supporting the income smoothing hypothesis in Islamic banking while Pramono et al. (2018) do not support income smoothing hypothesis in similar area. In case of conventional banks, Fonseca and Gonzalez (2008) found positive relationship between loan loss provision (LLP) and earning before tax and provision (EBTP) and support income smoothing behavior and further their finding suggest that income smoothing is sever in the developing countries than developed countries. However, Laeven and Majnoni (2003), Bryce et al. (2015) and Ahmed, Takeda and Thomas (1999) do not find an evidence on the existence of income smoothing. Thus, it shows that, income smoothing is not stable across countries and between different periods. Moreover, from provisioning practice perspective, Bryce et al. (2015) do not found evidence for the procyclicality of loan loss provision, while Aristei and Gallo (2019) found an evidence on the dynamic provision practices.

Even though dozens of literatures around the world examine the cyclicality of loan loss provision and banks income smoothing behavior, only Tendeloo \& Vanstraelen (2005), Barth, Landsman \& Lang (2008), and Leventis, Dimitropoulos \& Anandarajan (2011) tried to extensively examine the income smoothing practice in comparison of GAAP and IFRS even from the developed country banks perspective. Except Desta (2017), Ozili (2017), Amidu \& kuipo (2015) as cited in Ozili \& Outa (2017), and Ozili \& Outa (2018 and 2019), no sophisticated study investigates the cyclicality of LLP and income smoothing behavior in Africa. But these studies were also limited to the effect of IAS39, which is an incurred loss approach. Recently, international standard setters modify the provisioning standard by replacing IAS39 by IFRS 9 which is an expected loss approach. As a result, the incurred loss approach of provisioning would have different discretionary power and it would affect reporting quality differently. Moreover, According to Olszak et al. (2016) the cyclicality of loan loss provision is different from bank to bank as well as from country to country irrespective of difference in the economic factors, Basel minimum capital requirement and implemented accounting standards. However, the loan loss provision literature is still a vacuum in Ethiopia. Thus, it is valuable to investigate the cyclicality of loan loss provision and income smoothing practice from developing country bank's perspective in comparison of before and after adopting expected loss provisioning model.

As illustrated above, a number of studies since the 1990s have examined the issue of loan loss provision and its determinants as well as income smoothing behaviors in different countries. However, despite being rich, the literature discussed above suffers from some considerable gaps. First and foremost, there is no study in the current Ethiopian literature that has considered loan loss provision and income smoothing behavior of commercial banks. Due to the importance of the issue, this research investigates the cyclicality of loan loss provision and commercial banks income smoothing behavior in Ethiopia. Thus, this study contributes to the growing literature of loan loss provision in several ways: Firstly, this is the first study that tests the existence of income smoothing behavior of commercial banks in Ethiopia without a stock market. Secondly, this study examines whether income smoothing behavior is affected by the adoption of IFRS. Moreover, this study provides evidence on whether International Financial reporting standards (IFRS) contribute to enhance reporting quality. To answer this important question, this study tried to compare the loan loss provision cyclicality and income smoothing behavior of commercial banks before and after IFRS adoption.

During the last 5 years, the Ethiopian economy experienced significant volatility accompanied by the liquidity 
problem of banks, and high non-performing loan that reached the highest level in Africa i.e. $40 \%$ in development bank of Ethiopia and increased loan loss provision which exacerbate the economic shock (DBE,2019). Thus, the investigation of the cyclicality of loan loss provisions and the income smoothing behavior/practice of commercial banks is a self-evident issue for the stability of economic growth, specifically the financial system in Ethiopia. Therefore, this study expected to have tremendous benefits for bank regulators, standard setters, auditors, and investors. It also lights on the provision practice of Commercial banks in Ethiopia, and enables them to strengthen and evaluate the financial regulation system. It will also help the International Accounting standard setters to assess the effect of the current provisioning versions. In addition, it may also help auditors to estimate the possible risks from provisioning policies adopted. Finally, it may also help investors to consider the impact of managerial discretion through income smoothing on the reported financial figures.

The remaining part of this paper is structured in the following ways. Section 2 discusses the related literature and hypotheses regarding the loan loss provisioning cyclicality and income smoothing. Section 3 describes the methodology employed. Section 4 reports the empirical results, discussion and interpretation, and finally, section 5 presents conclusions.

\section{Literature Review and Hypothesis Formulation}

\subsection{Introduction}

Banks and regulators define a specific level of protection against credit losses and banks set aside loan-loss provisions according to the value of expected losses and raise capital according to unexpected losses. Loan loss provision is set aside for the probable losses. If the probability of the expected loss is likelihood, it would be compensated by the interest rate. Mean that, credit risk is built up in a prosperous and occurs in a recession, so banks should recognize the underlying risk and build up loan-loss provisions in good times to be drawn on in bad times. As a result, provisions may therefore move with income (income-smoothing pattern) and with the economic cycle to return the ratio to its ideal (equilibrium) value every time it is modified by a random shock. Even though the final result of any reason is connotative, there are different reasons which motive entities for income smoothing. unsurprisingly, income smoothing may be to improve the risk perception of investors, regulators, and supervisors. Even though, there may be managerial self-interest to smooth earnings, it may also be the result of perceived bankruptcy concerns and/or can be intended to discourage market entrants from entering to market that could then be used to trade without strong competition (Fonseca, \& Gonzalez, 2008; Desta, 2017; Alhadab \& Alsahawneh, 2016).

\subsection{Cyclicality of Loan Loss Provision}

Generally, the system of loan loss provision is categorized in to three: procyclical, countercyclical and dynamic provision. In procyclicality view of loan loss provisioning, it is expected that, banks set aside the provision amount after the occurrence of some objectively measured loss or loss indicators. It is the incurred loan loss provisioning approach which was defined by IAS 39. It is called back ward looking approach, which looks back on the incurred losses. According to this approach, banks are expected to increase loan loss provision when the economy down while they decrease loan loss provision when the economy boomed. To test this hypothesis, it is expected that, loan loss provision and economic growth (GDP) has negative relationship. Even though, the empirical result is mixed: most of the literatures support this approach (Fonseca \&Gonzalez, 2008; Leaven and Majnoni, 2003) thus it was hypothesized that:

H1a: Economic growth has significant negative effect on loan loss provision.

According to dynamic provisioning system, the provisioning decisions may be systematically related to each period leading to time persistency, and capture the speed of adjustment of LLPs to an equilibrium level (Aristei \& Gallo, 2019). Thus, to test the dynamic provisioning the lagged loan loss provision (LLP $\mathrm{i}_{\mathrm{t}-1}$ ) also included. In addition to this, in the dynamic provisioning system, loan loss provision is expected to be the proportion of loan amount, thus it was hypothesized that;

H1b: loan loss provision significantly and positively affected by its lagged value

Many empirical evidences witnessed that bank credit risk management is procyclical in general. In other words, banks tend to underestimate credit risk during economic boom, but overestimate it during economic downturn. Accordingly, the current loan loss provisioning system also tends to be procyclical with business cycle (Laeven \& Majnoni, 2003; Altman, Brady, Resti, \& Sironi, 2005; Bikker \& Metzemakers, 2005. Agenor and Pereira DaSilva, 2017 as cited in Kruger, Rosch \& Scheule, 2018), recommends dynamic provisioning regimes as tool of mitigation from such capital pressure. Thus, to test the dynamicity of provision, in addition to the lagged provision, it was hypothesized that:

H1c: Loan growth has significant negative effect on Loan loss provision

\subsection{Income Smoothing Hypothesis}

According to the income smoothing hypothesis, banks are expected to use loan loss provisions to smooth their 
income by overstating (understating) LLPs when incomes are expected to be high (low). In line with most of the empirical literature (Aristei \& Gallo, 2019; Desta, 2017), this study also uses the ratio of earnings before taxes and loan loss provisions to total assets $\left(\mathrm{EBTP}_{i \mathrm{t}}\right)$ to test the relationship between LLPs and income implied by the Income smoothing hypothesis. Ozili (2017) found an evidence that African banks smooth and the provisioning nature of loan loss is procyclical. As a result, the author suggests that dynamic LLP system is needed in Africa and based on this past empirical evidence it is hypothesized that:

H2a: Earning before tax and Provision has positive significant effect on loan loss provision

\subsection{Capital Management Hypothesis}

Capital management and the banks provision related through the credit risk concept. In the credit risk concept, expected losses are expected to be covered by the provisioned amount while the remaining loss expected to be covered by the bank capital. Thus, banks need to have a proper provisioning system to ensure that sufficient amount of profit reserved for non-performing loan mainly during financial difficulty. However, as per capital management hypothesis, banks are expected to increase loan loss provision to reduce the required regulatory capital and in the case of lower capital requirement commercial banks may reduce the loan loss provision amount (Aristei \& Gallo, 2019). To test whether banks use loan loss provisions to manage their regulatory capital (i.e., to make provisions to keep their capital ratio adequate when their capital is low) this paper uses the ratio of equity Capital to Total Asset $\left(\mathrm{CAP}_{\mathrm{i}, \mathrm{t}}\right)$. The traditional capital-management hypothesis states that bank managers use LLP to reduce expected regulatory costs associated with violating capital requirements, as a result a negative relationship being predicted between capital ratios and LLP. Thus, it was hypothesized as that:

H3. loan loss provision negatively and significantly affected by capital ratio.

The loan loss provisioning system of banks is changed from incurred loss approach in IAS39 and Basel regulation to expected loss approach in IFRS 9 and GAAP326 (Kruger, Rosch \& Scheule, 2018). However, there are two opposing views on IFRS: one view suggesting that IFRS should improve earnings quality and the other that it could reduce quality of reported earnings through discretionary provisioning system.

By using fixed effect regression, Ozili \& Outa (2018) investigate the income smoothing behavior in South Africa and found that South African banks do not use LLPs to smooth income when they are undercapitalized and moderately concentrated ownership but income smoothing is pronounced when they are more profitable during economic boom periods, well-capitalized during boom periods and is pronounced among banks that adopt IFRS. They also evident that banks use LLPs for capital management purposes, and bank provisioning is procyclical with economic fluctuations. Similarly, Ozili \& Outa (2018) have also examined the banks earning management During mandatory IFRS adopting in Nigeria, it was found that IFRS plays a controlling role in earning management. According to their finding, Nigerian banks do not use LLP for earning management purpose after mandatory IFRS adoption. surprisingly, they found that, Banks used LLP for earning management purpose during voluntary IFRS adoption.

As documented in different studies (Leventis, Mitropoulos \& Anandarajan, 2011; Alhadab \& Alsahawneh, 2016), LLPs are used by banks as a mechanism for aggressive earnings management, mainly for stock market purposes. This motivates the researcher to ask, is LLP also be mechanism of income smoothing in the absence of stock market? Thus, the researcher hypothesis that commercial banks use loan loss provisions for income smoothing before and after IFRS adoption.

H4: There is significant positive intervening effect of IFRS on the income smoothing behavior

\section{Research Methodology}

The extent literature suggests that there are two main components which could explain the loan loss provisioning behavior: non-discretionary component and discretionary component. As mentioned above, the non-discretionary component is related to the covering of expected losses and credit risk of bank portfolio. This factor, together with economic cycle, could be the indicator of cyclicality of loan loss provision. The main variables that this study consider to take into account the non-discretionary component are: the ratio of loans to total assets, LS i,t and GDP which serves as a proxy for expected loan losses and a positive relationship between this variable and loan loss provisioning is expected. The discretionary component of LLP results from three different management objective, such as: Income smoothing behavior, capital management behavior, and signaling behaviors. Based on the income smoothing theory, banks tend to increase (decrease) LLP when earnings are expected to be high (low). A positive relationship between earnings and LLP indicate that banks use provisions to smooth earning, while a negative relationship between these variables indicates procyclicality. The ratio of earnings before interest, taxes and loan loss provision over total assets (EBTP $i, t)$ have been used as a variable to test the income smoothing hypothesis. Besides, as indicated in Dushku (2016), capital to asset ratio $\left(\mathrm{CR}_{\mathrm{it}}\right)$ has been used to test the capital management hypothesis. A negative relationship between capital to asset ratio and loan loss provisions supports the capital management hypothesis: more provisioning when the capital ratio is relatively low. Loan loss provisions may also be used to signal financial strength. However, since there is no secondary market in Ethiopia, this hypothesis has 
deliberately ignored in this study. Furthermore, $G D P_{t}$ have been used as a proxy of business cycle conditions measured through real GDP growth, which is used to capture the procyclicality of loan loss provisions. A positive relationship between loan loss provisions and real GDP reflect the counter cycle behavior of banks, so they profit from better economic conditions to expand their reserve buffers (Leaven \& Majnoni, 2003; Dushku, 2016), ), while a negative link between these two variables indicates that banks create additional provisions as a result of economic downturn following a more pro-cyclical behavior. To test the effect of IFRS on the loan loss provision system and the income smoothing behavior of commercial banks, EBTP*IFRS have been used to test the interaction effect of income smoothing for IFRS adopters and in support of this, the two sub-period has been compared separately as robust. In addition to this, $\mathrm{NLA}_{i t}$ has been used as a proxy of natural logarithm of assets to control bank size effect. The sample used in this study is limited to 15 Private commercial banks in Ethiopia for ten (10) year period from 2010-2019. During the specific time frame (July first 2017), commercial banks were subjected to major regulatory change (the requirement to implement IFRS). The bank specific data were collected from each commercial bank annual report (balance sheet and income statement) and the macro economic data (gross domestic product) were collected from National bank of Ethiopia (NBE) annual report. The total number of commercial banks in Ethiopia are 18. Of which, one government owned commercial bank (to avoid survivorship biases because of the engagement in merger on 2015), one government development bank (because of its special nature) and one cooperative bank (because they have different provisioning practice Aristei \& Gallo, 2019)) were excluded from the sample. This procedure gives a final sample of 15 commercial banks with unbalanced panel study of 136 firmyear observations i.e. 91 before IFRS and 45 After IFRS adoption.

In order to examine the income smoothing behavior and the cyclicality loan loss provisioning system, following Ozili (2019), a pooled panel data model has been used following the appropriate test and the complete specification of the model used in the study was follows:

LLP $\mathrm{i}, \mathrm{t}=a_{0}+\beta 1$ EBTPA $\mathrm{i}, \mathrm{t}+\beta 2$ CAPA $\mathrm{i}, \mathrm{t}+\beta 3$ IFRS dummy $+\beta 4$ IFRS $*$ EBTPA $\mathrm{i}, \mathrm{t}+\beta 5$ IFRS $*$

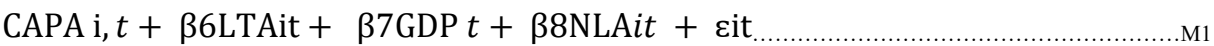

LLP $\mathrm{i}, \mathrm{t}$ is loan loss provision scaled for the beginning total Asset balance, LLP i, $\mathrm{t}-1$ is first and second lagged loan loss provision, CAP $i, t$ is capital ratio of the bank $i$ at time $t$, LTA $i, t$ is the total loan amount of bank $i$ at time $t$ scaled by total asset, GDP $t$ is the growth in gross domestic product, IFRS is an indicator variable (1) if the bank adopts IFRS, (0) otherwise, NLA i, $t$ is logarithm of total Asset and cit is an error term

The model in M1 is the static model and as an alternative the researcher used a dynamic model as a robustness test to capture adjustments to bank provisioning that extend beyond a one-year period and this adjustment is done by incorporating the lagged dependent variable as an explanatory variable into the main model as shown in M2 below. The complete specification of the dynamic model used as robust is therefore:

LLP $\mathrm{i}, \mathrm{t}=a_{0}+$ pLLP $\mathrm{i}, \mathrm{t}-1+\beta 1$ EBTPA $\mathrm{i}, \mathrm{t}+\beta 2$ CAPA $\mathrm{i}, \mathrm{t}+\beta 3$ LTAit $+\beta 4 \mathrm{GDP} t+\beta 5 \mathrm{NLAit}+$

Eit......M2

The inclusion of lags of the dependent variable may reduce the consistent of Ordinary Lest Square (OLS) estimation. Thus, to get consistent estimates of the above model, generalized method of moments (GMM) suggested by Arellano and Bond (1991) has been used. This procedure estimates the specific dynamic model in first-differences to solve the estimation problem raised by the potential presence of unobserved individual effective and gives consistent estimates under the assumption that the error term $\varepsilon_{\text {it }}$ is not serially correlated and the explanatory variables are (weakly) exogenous. It has been assumed that all explanatory variables are (weakly) exogenous. Under these assumptions, the first lag of the dependent variable was assumed a valid instrument and the difference estimator was expected to be an efficient GMM estimator for the above model (M2) robust test. However, the overall test of the GMM model reveled that GMM model is not valid for the given data. As a result, only the pooled OLS regression result has been reported and deeply analyzed.

\section{Result and Discussion}

Table 2 in the appendix, presents the descriptive statistics for both the pooled data and for the two different subperiods, period 1(2010-2016) and period 2 (2017-2019). Table 2 describes the continuous variables. Of the reported variables, loan loss provision (LLP), loan size (LS) and bank size (NLA) increase between the two sub periods while other variables decrease from sub-period 1 to sub-period 2. The Table (1a) below, provides some of the descriptive statistics about the main variables used for full estimation sample. The ratio of loan loss provisions to total assets equals 0.245 percent on average (with a standard deviation of 0.3 percent). According to Leventis, Dimitropoulos and Anandarajan (2011), after IFRS adoption, LLP have increased significantly in some countries (Hungary, Greece, Spain, France and UK), banks in other countries seem to have deteriorated levels of LLPS (Denmark, Germany, Norway, Poland and Portugal) while in a few countries banks' LLP levels have not changed significantly (Sweden, Italy, Belgium, Austria). In line with the literature, the unreported two-sample t-test, shows that loan loss provision significantly differed after the adoption of IFRS. 
The ratio of earnings before taxes and provisions to total assets equals 3.6 percent, the average rate of loan size equals to 45.32 percent, and the ratio of capital to total asset equals 15.6 percent.

Table 1a. Summary of Descriptive Statistics

\begin{tabular}{|l|l|l|}
\hline Variable & Mean & Standard deviation \\
\hline LLP & 0.00247 & 0.0030047 \\
\hline EBTP & 0.0369334 & 0.0121688 \\
\hline LS & 0.4531963 & 0.0703651 \\
\hline CR & 0.1597933 & 0.050335 \\
\hline
\end{tabular}

Pearson correlations presented in table 3 (appendix) indicate that all of the variables have correlations below 0.7. According to Guajarati (2004), this indicates that all variables are not highly inter-correlated. Moreover, the Variance Inflation Factor (VIF) presented in table 4 (appendix), have also been used and reported to test the multicollinearity problem for each sub period regressions (not reported) and the full sample period (reported). The mean and individual VIF are near to 1 and thus show low correlations among variables and do not raise any multicollinearity concerns. The correlation table also shows that, EBTP has negative relationship with LLP indicating that LLP increased while EBTP reduced and vice versa. Based on the stated hypothesis and the criteria of Laeven and Majnoni (2003), it is against the income smoothing behavior hypothesis. The correlation between LLP and the remaining independent variables is positive. Olszak et al. (2016) states that when the business cycle of the country linked negatively with the LLP of commercial banks, it is called procyclical provisioning system while the positive relationship shows the countercyclical provisioning system. Having this empirical evidence, the descriptive analysis of this study shows that the correlation between the LLP and capital ratio supports the capital management hypothesis while the relationship of LLP, loan amount and Economic growth (GDP) revealed that the loan loss provision of commercial banks in Ethiopia is countercyclical.

In addition, panel unit root test has been run for the whole sample. The literature provides a variety of tests for unit roots or stationery in panel datasets. For this study, which is based on unbalanced data, Fisher-type unit root test has become appropriate and has been used, the inverse normal $Z$ statistic, the result indicates that, all continuous variables are stationary at their zero level as presented in table 6 (Appendix). Fixed effects, pooled OLS and random effects approaches are commonly used models for the panel data. In order to choose those alternative approaches, a formal test so called F-test, LM-test, and Hausman test has been applied and based on the test result, pooled OLS model has become appropriate.

Table 7 below presents the estimation results of loan loss provisioning model. The result revealed that there is negative and significant effect of Earning before tax and provision on loan loss provisions during the first subperiod (i.e. GAAP) with coefficient of -2.520519 , while it was positive and significant with coefficient of 0.083163 at sub-period 2 (i.e. IFRS). The full period with IFRS dummy and interaction effect of IFRS and EBTP depict that IFRS has significant intervene role in income smoothing behavior of commercial banks. So, it supports the argument that, there is discretionary loan loss provisioning after IFRS adoption. Entirely, this paper result is in line with Ahmed et al. (1999); Laeven and Majnoni (2003), Bryce et al. (2015), and Aristei \& Gallo (2019) while it is against the work of Fonseca and Gonzalez (2008) result for: Brazil, Chile, Denmark, Egypt, Italy, Kenya, Korea, Peru, Philippines, Portugal, Spain, Sweden, and Venezuela) but it is in line with the loan loss provisioning practice of: Colombia, Greece, Malaysia, Pakistan, Thailand, and the United Kingdom (Fonseca and Gonzalez, 2008, El Sood, 2012, Othman \& Mersni, 2014 and Barth et al., 2008). In contrary to the result of Tendeloo and Vanstraelen (2005), this study finds that there is significant difference on income smoothing before and after IFRS adoption in Ethiopian commercial banks. Novotny-Farkas (2016) suggest that to yield the expected benefit of the introduced new provision approach (expected loan loss provision) the consistent and proper application of the rules is needed. In a similar talk, it needs the integrated work of preparers, auditors, supervisors and other regulatory bodies. The result of this study also suggest that the National bank of Ethiopia (NBE) and the Accounting and Audit Board of Ethiopia (AABE) need to have an integrated task force to follow up the consistent IFRS application. 
Table 7: OLS Estimation Result

\begin{tabular}{|l|l|l|l|}
\hline Variable & $\begin{array}{l}\text { Sub-period 1 } \\
(2010-2016)\end{array}$ & $\begin{array}{l}\text { Sub-period 2 } \\
(2017-2019)\end{array}$ & $\begin{array}{l}\text { Full sample period }(2010- \\
2019)\end{array}$ \\
\hline EBTP & $-2.520519^{*}(1.361)$ & $083163^{* *}(.0213)$ & $-3.066126^{* *}(1.29)$ \\
CR & $.38227 * *(.145)$ & $-.0100161(.014)$ & $.1104884^{*}(.064)$ \\
LS & $-.5519704(.693)$ & $.0412054^{* *}(0176)$ & $.1069361(.282)$ \\
GDP & $-.0641389(.061)$ & $0055655(.005)$ & $.0811963(.15)$ \\
NLA & $-.2471432 * *(.118)$ & $-.0203143^{* *}(.005)$ & $.2019648^{* *}(.065)$ \\
IFRS & & & $0.156222^{* *}(0.077)$ \\
IFRS*EBTP & & & $-10.73259^{* *}(3.89)$ \\
IFRS*CR & $7.509321^{* *}(2.141)$ & $-2.684834^{* *}(.097)$ & $-.1961698(.16)$ \\
Cons. & 0.0014 & 0.0000 & $-7.2588^{* *}(.96)$ \\
Prob $>$ F & 0.1473 & 0.4896 & 0.0001 \\
Adj $R$-squared & 91 & 45 & 0.1716 \\
Number of obs. & 91 & 136 \\
\hline
\end{tabular}

Note: The regressions are estimated using pooled ordinary least squares (OLS) for the whole sample period 20102019 and for each sub-sample period. Dependent variable is the ratio of loan loss provisions over total assets. EBPT equals profits before tax and loan loss provisions over total assets. Loan size equals total loan over total asset, GDP growth is real growth in per capita GDP. The IFRS dummy takes value one if banks adopt IFRS and zero otherwise. The standard errors are reported in brackets (* Significance at a 10\% level and ** Significance at a $5 \%$ level).

Furthermore, the pooled OLS estimation result shows that capital ratio has significant positive effect on loan loss provision during sub-period 1 and for the whole period. The positive sign indicates that, there is capital management practice using loan loss provision. The coefficient of capital ratio (CR) in sub-period 2 shows negative but insignificant effect. With the coefficient of IFRS*CR (interaction effect at full sample period), the negative sign implies that there is improvement in capital management behavior of commercial banks after the adoption of international Financial Reporting standard but it is insignificant. Similarly, this study eco the argument of Ahmed et al. (1999) and from capital management perspective this research result is in line with Leventis et al. (2011). Based on the estimation result, this study argued that even though there is an intervention role, IFRS could not able to reduce the capital management practice of commercial banks in Ethiopia.

The cyclicality hypothesis of loan loss provision has been hypothesized by three different robust proxies. The first assumed proxy of loan loss provision cyclicality was the lagged dependent variable using the GMM model. However, the overall test of the model failed to use this proxy as robust measurement. The second alternative proxy of procyclicality of loan loss provision hypothesis supposed that loan loss provision affected insignificantly by the economic growth i.e. GDP. The estimation result in Table 7 above revealed that, GDP have no significant effect on LLP both before and after IFRS. Thus, it shows that the loan loss provisioning practice of Ethiopian commercial banks is not procyclical. Moreover, the coefficient of loan size depicts that the provision practice of loan loss provision was not dynamic before IFRS adoption but after IFRS adoption commercial banks adopt a dynamic provision system.

\section{Conclusion and Recommendation}

This study examined the cyclicality of loan loss provision and the income smoothing behavior of commercial banks in Ethiopia. This study used pooled OLS regression model to test the income smoothing and cyclicality of loan loss provision hypothesis. The findings indicate that Ethiopian commercial banks were not use LLP for income smoothing behavior, however, after IFRS adoption, commercial banks use LLP as income smoothing tool. Based on this, it is concluded that IFRS weakens the reporting quality of commercial banks in Ethiopia. The implication is that IFRS adoption has lower accounting quality in Ethiopian commercial banks based on loan loss provision during the examined period. However, IFRS adoption enhanced the capital management practice. Furthermore, the finding of this paper revealed that the provisioning practice of commercial banks was countercyclical before IFRS adoption and after IFRS adoption it changed to dynamic provision system. The Finding of this study suggests that national bank of Ethiopia and the reporting regulators (AABE and its councils) should strictly follow up and take the corrective action on IFRS based financial reporting of commercial banks.

\section{Abbreviations}

AABE: Accounting and Audit board of Ethiopia; CAP: Capital; EBTP: Earning before tax and provision; GAAP: Generally accepted accounting principles; GDP: Gross domestic product; GMM: Generalized method of moments; IAS: International accounting standard; IFRS: International Financial reporting standard; LLP: Loan loss provision; LM: Lagrange multiplier; LS: loan size; NBE: National bank of Ethiopia; NLA: Natural Logarithm of asset; OLS: 
Ordinary lest square; UK: United Kingdom.

Acknowledgment: Not applicable

Funding: This research is done by the researcher himself and no funding opportunity from any source.

Availability of Data and Materials: The datasets used and/or analyzed during the current study will be available on reasonable request.

Competing Interest: The author declare that he have no competing interests in this manuscript.

\section{References}

Ahmed, S.A., Takeda, C. \& Thomas, S. (1999). Bank loan loss provisions: a reexamination of capital management, earnings management and signaling effects; Journal of Accounting and Economics Vol. 28 PP. 1-25; https://doi.org/10.1016/s0165-4101(99)0017-8.

Alhadab, M.\& Alsahawneh, S. (2016). Loan Loss Provision and the Profitability of Commercial Banks: Evidence from Jordan; International Journal of Business and Management; Vol. 11, No. 12. http://doi.org/10.5539/ijbm.v11n12p242.

Altman, E.I., Brady, B., Resti, A., \& Sironi, A. (2005). The link between default and recovery rates: Theory, empirical evidence, and implications; Journal of Business Vol. 78, No. 6, pp. 2203-2228. http://doi.org/10.1086/497044.

Aristei, D. \& Gallo, M. (2019). Loan loss provisioning by Italian banks: Managerial discretion, relationship banking, functional distance and bank risk; International Review of Economics and Finance Vol. 60, PP. 238-256, https://doi.org/10.1016/j.iref.2018.10.022.

Barth, M. E., Landsman, W. R., \& Lang, M. H. (2008). International accounting standards and accounting quality.; Journal of Accounting research Vol. 46, PP. 467-498, https://doi.org/10.1111/j.1475-679x.2008.00287.x.

Boudriga, A., Zouari, S.B. \&Taktak, B. N. (2010). Do Islamic banks use loan loss provisions to smooth their results; Journal of Islamic Accounting and Business Research Vol. 1 No. 2, pp. 114-127 Emerald Group Publishing Limited; DOI: https://doi.org10.1108/17590811011086714.

Bryce, C., Dadoukis, A., Hall, M., Nguyen, L. \& Simper, R. (2015). An Analysis of loan loss provisioning behavior in Vietnamese banking, Finance Research Letters; doi :http://doi.org/10.1016/j.frl.2015.05.014.

DBE. (2019). Development bank of Ethiopia report retrieved from https://www.dbe.com.et.

Dermine, J. \& Carvalho, C.N. 92008). Bank loan-loss provisioning, central bank rules vs. estimation: The case of Portugal; Journal of Financial Stability vol. 4 PP. 1-22, doi: http://doi.org/10.1016/j.jfs.2007.12.001.

Desta, T.S. (2017). Consequence of loan loss provisions on earnings management behavior: A study on the best African commercial banks; South African Journal of Business and Management Vol. 48, No. 3;Dol: https://doi.org/10.4102/sajbm.v48i3.31.

Dushku, E. (2016). Some Empirical Evidence of Loan Loss Provisions for Albanian Banks. Journal of Central Banking Theory and Practice, Vol. 2, pp. 157-173, https://doi.org/10.1515/jcbtp-2016-0016.

El Sood, A. (2012). Loan loss provisioning and income smoothing in US banks pre and post the financial crisis; International Review of Financial Analysis Vol. 25, PP. 64-72, https://doi.org/j.irfa.2012.06.007.

Fonseca, R. A. \& Gonzalez, F. (2008). Cross-country determinants of bank income smoothing by managing loanloss provisions; Journal of Banking \& Finance Vol.32, PP. 217-228, https://doi.org/10.1016/j.jbankfin.2007.02.012.

Gujarati, D.N. (2004). Basic econometric, $4^{\text {th }}$ edition, MCGraw-hill companies

Kruger, S., Rosch, D. \& Scheule, H. (2018). The impact of loan loss provisioning on bank capital requirements; Journal of Financial Stability Vol. 36, PP. 114-129, https://doi.org/10.1016/j.jfs.2018.02.009.

Laeven, L. and Majnoni, G. (2003). Loan loss provisioning and economic slowdowns: too much too late? Journal of Financial Intermediation, Vol. 12, No.2, PP.178-197, doi: https://doi.or/10.1016/S1042-9573(03)00016-0.

Leventis, S., Dimitropoulos, E.P, \& Anandarajan, A. (2011). Loan Loss Provisions, Earnings Management and Capital Management under IFRS: The Case of EU Commercial Banks; Journal of Finance Vol. 40, PP. 103122, https://doi.org/10.1007/s10693-010-0096-1.

Novotny-Farkas, Z. (2016). The Interaction of the IFRS 9 Expected Loss Approach with Supervisory Rules and Implications for Financial Stability, Accounting in Europe, Vol. 13, No.2, PP. 197-227, http://doi.org/10.1080/17449480.2016.1210180.

Olszak, M., Pipien, M., Kowalska, I \& Roszkowska, S. (2016). What Drives Heterogeneity of Cyclicality of LoanLoss Provisions in the EU? Journal of Finance Serv Res, DOI: https://doi.or/10.1007/s10693-015-0238-6.

Othman, B.H \& Mersni, H. (2014). The use of discretionary loan loss provisions by Islamic banks and conventional banks in the Middle East region: A comparative study; Studies in Economics and Finance Vol. 31 No. 1, pp. 106-128, http://doi.org/10.1108/SEF-02-2013-0017.

Ozili, K.P. \& Outa, E. (2017). Bank loan loss provisions research: A review, Borsa Istanbul Review, Vol. 17, No. 3, PP. 144-163 https://dx.doi.org/10.1016/j.bir.2017.05.001.

Ozili, P. k. \& Outa, E.R. (2018). Bank income smoothing in South Africa: role of ownership, IFRS and economic 
fluctuation, International Journal of Emerging Markets, Vol. 13 No. 5, pp. 1372-1394, https://doi.org/10.1108/IJoEM-09-2017-0342.

Ozili, P.K. \& Outa, E.R. (2018). Bank earnings smoothing during mandatory IFRS adoption in Nigeria, African Journal of Economic and Management Studies, https://doi.org/10.1108/ AJEMS-10-2017-0266.

Ozili, P.K. (2017). Bank earnings smoothing, audit quality and procyclicality in Africa: The case of loan loss provision, Review of Accounting and Finance, Vol. 16 No. 2, pp. 142-161, https://doi.org/10.1108/RAF-122015-0188.

Ozili, P.K. (2019). Bank Loan Loss Provisions, Risk-taking and Bank Intangibles. Afro-Asian Journal of Finance and Accounting, Vol. 9, No. 1, pp.21-39. https://ssrn.com/abstract=3108341.

Pool, S., Haan, L., Jacobs, J. P. (2015). Loan loss provisioning, bank credit and the real economy; Journal of Macroeconomics Vol. 45 PP. 124-136, https://doi.org/10.1016/j.macro.2015.04.006.

Tendeloo, B. \& Vanstraelen, A. (2005). Earnings management under German GAAP versus IFRS. European Accounting Review Vol. 4, No.1, PP. 155-180, https://doi.org/10.1080/0963818042000338988.

\section{Appendix}

Table 1: Measurement and Notations of Variables

\begin{tabular}{|l|l|l|}
\hline Variable & Notation & Measurement \\
\hline Loan loss provision & LLP & Loan loss provision scaled by total Asset \\
\hline Profitability & EBTP & Earning before tax and provision scaled by total Asset \\
\hline Loan size & LS & Total loan scaled by total Asset \\
\hline Gross domestic product & GDP & Real gross domestic product \\
\hline Capital ratio & CR & Total capital of bank/Total Asset \\
\hline IFRS & IFRS & Dummy: (1) if the bank adopts IFRS (0) otherwise \\
\hline Firm size & NLA & Natural logarithm of Total Asset \\
\hline
\end{tabular}

Table 2 Descriptive Statistics

\begin{tabular}{|lllll|}
\hline Variable & & Subperiod 1 & Sub period 2 & All years \\
& & $2010-2016$ & $2017-2019$ & \\
\hline LLPit & Mean & 0.0024803 & 0.0025559 & 0.00247 \\
& SD & 0.003417 & 0.0020414 & 0.0030047 \\
EBTPit & $\mathrm{N}$ & 91 & 45 & 136 \\
& Mean & 0.0382926 & 0.0335231 & 0.0369334 \\
& $\mathrm{SD}$ & 0.0137119 & 0.007813 & 0.0121688 \\
CRit & $\mathrm{N}$ & 91 & 45 & 136 \\
& Mean & 0.1674153 & 0.1450033 & 0.1597933 \\
& $\mathrm{Sd}$ & 0.0563644 & 0.323822 & 0.050335 \\
LSit & $\mathrm{N}$ & 91 & 45 & 136 \\
& $\mathrm{Mean}$ & 0.430307 & 0.4947883 & 0.4531963 \\
NLAit & $\mathrm{Sd}$ & 0.0551107 & 0.0765286 & 0.0703651 \\
& $\mathrm{~N}$ & 91 & 45 & 136 \\
GDPt & Mean & 6.522996 & 6.976308 & 6.619281 \\
& $\mathrm{SD}$ & 0.7353289 & 0.7479147 & 0.8554974 \\
& $\mathrm{~N}$ & 91 & 45 & 136 \\
& $\mathrm{Mean}$ & 9.877778 & 8.975 & 9.555882 \\
& $\mathrm{Sd}$ & 1.079615 & 1.03482 & 1.151473 \\
& $\mathrm{~N}$ & 91 & 45 & 136 \\
\hline
\end{tabular}

Table 3: Pearson Correlation

$\begin{array}{lccccccc} & \text { LLPN } & \text { EBTP } & \text { LS } & \text { CR } & \text { NLA } & \text { GDP } & \text { IFRS } \\ \text { LLPN } & 1.0000 & & & & & & \\ \text { EBTP } & -0.2282 & 1.0000 & & & & & \\ \text { LS } & 0.0991 & -0.0828 & 1.0000 & & & \\ \text { CR } & 0.2168 & 0.0532 & 0.2973 & 1.0000 & & \\ \text { NLA } & 0.2336 & 0.0446 & 0.4040 & 0.3011 & 1.0000 & \\ \text { GDP } & 0.0212 & 0.0499 & -0.3749 & -0.0426 & -0.2741 & 1.0000 & \\ \text { IFRS } & 0.0027 & 0.1787 & -0.4971 & -0.1717 & -0.4322 & 0.3787 & 1.0000\end{array}$


Table 4: Variance inflation factor (VIF)

$\begin{array}{lcc}\text { Variable } & \text { VIF } & 1 / \text { VIF } \\ \text { LS } & 1.28 & 0.780161 \\ \text { CR } & 1.18 & 0.850878 \\ \text { GDP } & 1.16 & 0.862700 \\ \text { NIA } & 1.11 & 0.896960 \\ \text { EBTP } & 1.06 & 0.946456 \\ \text { Mean VIF } & 1.16 & \end{array}$

Table 5: t-test

One-sample $t$ test

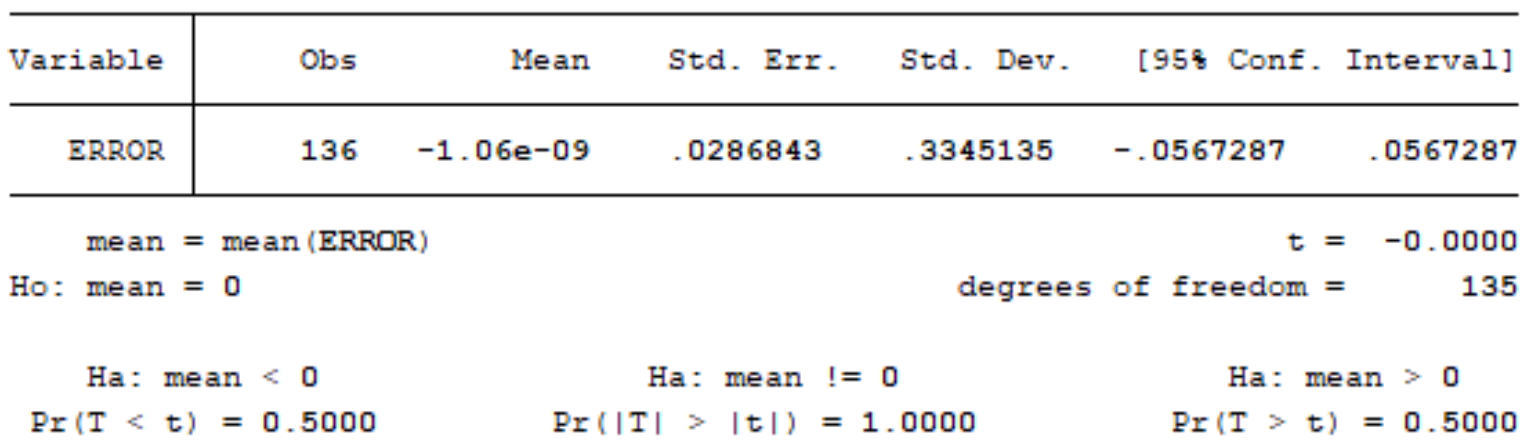

Table 6: Unit Root Test

\begin{tabular}{|l|l|l|}
\hline Variable & z-statistics & P-value \\
\hline LLP & -7.1232 & 0.0000 \\
\hline EBTP & -3.8587 & 0.0001 \\
\hline CR & -2.0221 & 0.0216 \\
\hline LS & -3.2933 & 0.0005 \\
\hline NLA & -8.214 & 0.000 \\
\hline GDP & -6.0049 & 0.0000 \\
\hline
\end{tabular}

